\title{
Penerapan Metode GARCH-Vine Copula untuk Estimasi Value at Risk (VaR) pada Portofolio
}

\author{
Herida Okta Pintari dan Retno Subekti \\ Program Studi Matematika, Universitas Negeri Yogyakarta, Jl. Colombo No. 1, Caturtunggal, Depok, \\ Sleman, Yogyakarta 55281, Indonesia \\ Korespondensi; Herida Okta Pintari, Email: heridaokta14@gmail.com; Retno Subekti, Email: \\ retnosubekti@uny.ac.id
}

\begin{abstract}
Abstrak
Salah satu alat ukur yang digunakan untuk menghitung risiko portofolio adalah Value at Risk (VaR). Beberapa metode pengukuran $\mathrm{VaR}$ mengasumsikan return berdistribusi normal dan ukuran dependensi antar saham menggunakan korelasi linear. Faktanya, asumsi normalitas pada data finansial jarang terpenuhi dan terdapat indikasi adanya heteroskedastisitas. Selain itu, kebergantungan antar saham yang non-linear tidak sesuai apabila diukur dengan korelasi linear. Penyimpangan ini menyebabkan tidak validnya estimasi VaR. Tujuan dari penelitian ini adalah untuk mengetahui penerapan metode GARCH-Vine Copula untuk estimasi VaR pada portofolio. Vine Copula adalah fungsi distribusi multivariat yang menggabungkan distribusi marginal return univariat dalam portofolio, dan dapat menggambarkan struktur kebergantungan non-linearnya. Vine Copula dapat dilakukan dengan menentukan dekomposisi Vine Copula dan fungsi keluarga copulanya. Dekomposisi Vine Copula dilakukan dengan menggunakan C-Vine dan D-Vine Copula. Kemudian dengan menggunakan fungsi copula keluarga Archimedean, yaitu Clayton, Gumbel, dan Frank dapat ditentukan distribusi bersamanya. Pembentukan distribusi marginal menggunakan model GARCH berdistribusi Student-t digunakan untuk mengatasi adanya heteroskedastisitas. Hasil penerapan dari tiga saham perbankan, yaitu BBNI, BBRI, dan BMRI periode 26 Agustus 2013 hingga 20 November 2017 diperoleh model D-Vine Copula dengan fungsi copula Frank adalah model terbaik untuk memodelkan data, dengan nilai VaR sebesar $1,86 \%, 2,56 \%$, dan $4,49 \%$ dari dana investasi pada tingkat kepercayaan $90 \%, 95 \%$, dan $99 \%$.
\end{abstract}

Kata Kunci: Value at Risk; Vine Copula; GARCH; Portofolio

\begin{abstract}
One of the measurement instrument that are used to calculate the risk of portfolio is Value at Risk (VaR). Several methods of measuring VaR assumes normal and the size of dependencies return between the stock using a linear correlation. Basically, the assumption normal in financial data is violated and the possibility of heteroscedasticity is indicated. In addition, dependences non-linear is not appropriate when measured with a linear correlation. This deviation causes invalidity VaR estimation. The purpose of this research is to know the application of GARCH-Vine Copula method for estimation of VaR on portfolio. Vine Copula is a multivariate distribution function that combines the univariate marginal distribution of return in portfolio, and it can describe the structure of dependencies nonlinear. Vine Copula can be done by determining the decomposition of Vine Copula and its copula family function. Vine Copula decomposition is using C-Vine and D-Vine Copula. Then by using the copula function of the Archimedean family, namely Clayton, Gumbel, and Frank can be determined the joint distribution. The facts, the formation of the marginal distribution of GARCH model using the student-t distribution used to overcome the presence of heteroscedasticity. The result of the application of these stocks namely BBNI, BBRI, and BMRI from 26 August 2013 to 20 November 2017 has shown model D-Vine Copula copula functions with Frank is the best one to model the data. So, the VaR estimation at $90 \%, 95 \%$, and $99 \%$ confidence levels are $1,86 \%, 2,56 \%$, and $4,49 \%$ respectively of the invested funds.
\end{abstract}

Keywords: Value at Risk; Vine Copula; GARCH; Portfolio 


\section{Pendahuluan}

Portofolio merupakan kombinasi atau gabungan atau sekumpulan aset baik berupa aset riil maupun aset finansial yang dimiliki oleh investor (Halim, 2005). Pengukuran risiko atas suatu portofolio merupakan hal yang sangat penting agar investor dapat memperoleh keuntungan maksimal dengan risiko seminimal mungkin. Salah satu alat ukur yang dapat digunakan untuk menghitung risiko terbesar pada portofolio adalah Value at Risk (VaR). VaR adalah estimasi kerugian maksimum yang akan diperoleh selama periode waktu tertentu pada tingkat kepercayaan tertentu (Jorion, 2002).

Salah satu metode perhitungan VaR yang banyak digunakan adalah metode variansi-kovariansi. Metode ini mengasumsikan return berdistribusi normal dan kebergantungan antar saham dapat diukur dengan korelasi linear. Pada dasarnya data finansial memiliki dua sifat penting, yaitu bersifat fat tails yang ditandai dengan kurtosis bernilai positif, dan adanya volatility clustering (Bollerslev, 1994). Selain itu, asumsi normalitas pada data finansial jarang dipenuhi dan struktur kebergantungan antar saham merupakan kebergantungan yang non-linear. Penyimpangan ini mengakibatkan tidak validnya estimasi VaR sehingga risiko yang diperoleh lebih besar dari risiko yang ditetapkan. Untuk mengatasi kelemahan tersebut, diperkenalkan suatu fungsi yaitu copula.

Copula merupakan suatu fungsi yang dapat menggabungkan beberapa distribusi marginal menjadi distribusi bersama (Suharto, 2017). Pada analisis statistika multivariat, copula digunakan sebagai pendekatan yang berguna untuk mempelajari kebergantungan tak linear antar kejadian dalam kasus multivariat. Sehingga copula dapat memodelkan struktur kebergantungan antar saham dan cukup fleksibel untuk memodelkan data return finansial yang tidak memenuhi sifat-sifat distribusi normal. Beberapa peneliti telah mengaplikasikan Copula untuk menghitung nilai risiko dari portofolio saham yang cenderung memiliki volatilitas tinggi. Dharmawan (2014) mengaplikasikan t-Copula untuk mengestimasi VaR portofolio yang terdiri dari indeks Jakarta Stock Exchange dan indeks Kuala Lumpur Stock Exchange. Kemudian Renggani, Pintari, dan Subekti (2017) mengestimasi nilai VaR portofolio menggunakan Elliptical Copula untuk portofolio bivariat dari indeks saham LQ45 yaitu, PTBA dan BBRI.

Pemodelan dengan Copula memiliki beberapa kelemahan, yaitu pada kasus multivariat, penentuan fungsi copula sulit untuk dilakukan dan keluarga yang dapat digunakan terbatas. Selain itu, copula hanya dapat memodelkan struktur kebergantungan yang terlalu sederhana (Geidosch, 2016). Untuk itu, apabila struktur ketergantungan antar saham lebih kompleks dan lebih mengeksplorasi adanya ketergantungan berpasangan antar saham pada portofolio multivariat maka dapat digunakan perhitungan VaR dengan menggunakan Vine Copula. Vine Copula merupakan fungsi distribusi multivariat yang menggabungkan distribusi marginal, sekaligus dapat menggambarkan struktur kebergantungan nonlinearnya. Konsep dari Vine Copula adalah mendekomposisi fungsi copula multivariat menjadi fungsi copula berpasangan (copula bivariat). Fungsi copula berpasangan ini diperoleh dari keluarga copula bivariat (Joe, 1997). Model Vine Copula memerlukan distribusi marginal sebelum menggabungkannya menjadi distribusi bersama. Umumnya, data finansial mengindikasikan adanya sifat heteroskedastisitas, sehingga pada pembentukan distribusi marginal dilakukan dengan menggunakan metode GARCH untuk menghilangkan efek heteroskedastisitas tersebut.

Berdasarkan paparan tersebut, maka penelitian ini bertujuan untuk menerapkan perhitungan Value at Risk pada portofolio menggunakan metode GARCH-Vine Copula, khususnya pada portofolio multivariat. Sehingga investor dapat mengetahui risiko yang akan diperoleh apabila berinvestasi pada suatu portofolio.

\section{Landasan Teori}

\section{Return}

Return merupakan salah satu faktor yang memotivasi investor untuk berinvestasi karena dapat menggambarkan secara nyata perubahan harga. Rumus return $\left(R_{t}\right)$ dari aset tunggal dapat dihitung dengan rumus berikut (Tsay, 2005)..

$$
R_{t}=\frac{P_{t}-P_{t-1}}{P_{t-1}}
$$


dengan $P_{t}$ adalah harga saham periode sekarang dan $P_{t-1}$ adalah harga saham periode sebelumnya. Sehingga persamaan return portofolio $\left(R_{p}\right)$ yang terdiri dari $n$ saham adalah sebagai berikut:

$$
R_{p}=\sum_{t=1}^{n} w_{t} R_{t}
$$

dengan $w_{t}$ adalah bobot masing-masing saham.

\section{Uji Kolmogorov Smirnov}

Uji Kolmogorov Smirnov dapat digunakan untuk menguji kenormalan data (Siegel, 1990). Hipotesis pada uji Kolmogorov Smirnov adalah sebagai berikut

$H_{0}$ : Data berasal dari populasi berdistribusi normal

$H_{1}$ : Data tidak berasal dari populasi berdistribusi normal

Statistik Uji:

$$
D=\operatorname{Sup}_{x}\left|S_{(x)}-F_{0}(x)\right|
$$

Dengan,

$S_{(x)} \quad$ : nilai distribusi kumulatif sampel

$F_{0}(x)$ : nilai distribusi kumulatif distribusi normal

$\operatorname{Sup}_{x}$ : nilai supremum untuk semua $x$ dari $\left|S_{(x)}-F_{0}(x)\right|$

Apabila nilai $D_{\text {hit }}>D_{(1-\alpha), n}$ maka diambil keputusan tolak $H_{0}$ dengan $D_{(1-\alpha), n}$ merupakan nilai tabel Kolmogorov-Smirnov pada kuantil (1-) dan $\mathrm{n}$ merupakan banyaknya observasi.

\section{Proses Autoregressive Moving Average (ARIMA)}

Model Autoregressive (AR) dengan order $p$ dinotasikan dengan AR $(p)$ atau $\operatorname{ARIMA}(p, 0,0)$. Menurut (Wei, 2006) bentuk umum $\operatorname{AR}(p)$ dapat dinotasikan sebagai:

$$
Y_{t}=\phi_{1} Y_{t-1}+\cdots+\phi_{p} Y_{t-p}+\varepsilon_{t}
$$

Bentuk umum model Moving Average pada tingkat order $q$ yang dapat dituliskan $\operatorname{MA}(q)$ atau ARIMA $(0,0, q)$ didefinisikan sebagai:

$$
Y_{t}=\varepsilon_{t}-\theta_{1} \varepsilon_{t-1}-\cdots-\theta_{q} \varepsilon_{t-q}
$$

Model Autoregressive Moving Average (ARMA) merupakan suatu bentuk kombinasi antara proses autoregressive dan moving average yang sering disebut dengan proses ARMA dengan ordo $p$ dan $q$ yang ditulis $\operatorname{ARMA}(p, q)$ atau $\operatorname{ARIMA}(p, 0, q)$. Bentuk umum model ini adalah:

$$
Y_{t}=\phi_{1} Y_{t-1}+\cdots+\phi_{p} Y_{t-p}+\varepsilon_{t}-\theta_{1} \varepsilon_{t-1}-\cdots-\theta_{q} \varepsilon_{t-q}
$$

Model Autoregressive Integrated Moving Average (ARIMA) merupakan model ARMA $(p, q)$ yang tidak stasioner. Bentuk umum model $\operatorname{ARIMA}(p, d, q)$ adalah:

$$
(1-B)^{d}\left(Y_{t}-\phi_{1} Y_{t-1}-\cdots-\phi_{p} Y_{t-p}\right)=\varepsilon_{t}-\theta_{1} \varepsilon_{t-1}-\cdots+\theta_{q} \varepsilon_{t-q}
$$

Identifikasi model ARIMA dapat dilakukan melalui pemeriksaan plot ACF yang menunjukkan order $q$ dan PACF yang menunjukkan order $q$. 
Pengujian signifikansi parameter dapat dilakukan melalui tahapan berikut.

1. Hipotesis

$$
\begin{aligned}
& \text { AR (Autoregressive) } \\
& H_{0}: \phi=0 \text { vs } H_{1}: \phi \neq 0 \\
& \text { MA (Moving Average) } \\
& H_{0}: \theta=0 \text { vs } H_{1}: \theta \neq 0
\end{aligned}
$$

2. Statistik Uji

$$
\begin{aligned}
& t_{\text {hit }}(A R)=\frac{\widehat{\phi}}{S E(\widehat{\phi})} \\
& t_{\text {hit }}(M A)=\frac{\widehat{\theta}}{S E(\widehat{\theta})}
\end{aligned}
$$

dengan $\hat{\phi}$ adalah estimator dari $\phi, \hat{\theta}$ adalah estimator dari $\theta, S E(\hat{\phi})$ adalah standar error yang diestimasi dari $\phi$, dan $S E(\hat{\theta})$ adalah standar error yang diestimasi dari $\theta$.

3. Kriteria keputusan: Tolak $H_{0}$ jika $\left|t_{h i t}\right|>t_{\frac{\alpha}{2}} ; d f=n-n_{p}$ atau $p-$ value $<\alpha$

\section{Uji Ljung Box dan Uji Lagrange Multiplier}

Setelah model runtun waktu diperoleh, maka perlu dilakukan pemeriksaan untuk mengetahui apakah residual yang dihasilkan bersifat white noise atau tidak dengan menggunakan uji Ljung-Box $(Q)$ yang dihitung dengan nilai residual $r_{k}$ dengan hipotesis sebagai berikut.

$H_{0}: r_{1}=r_{2}=\cdots=r_{K}=0$ vs $H_{1}:$ minimal ada satu $r_{k} \neq 0$ untuk $k=1,2, \ldots K$

Statistik Uji:

$$
Q=n(n+2) \sum_{k=1}^{K} \frac{r_{k}^{2}}{n-k}
$$

dengan $n$ adalah banyak observasi, $k$ adalah banyak lag yang diuji, dan $r_{k}$ adalah sampel ACF dari residual lag- $k$ (Hanke, 2005). Keputusan terhadap hipotesis autokorelasi residual didasarkan apabila nilai $Q \leq x_{[\alpha: d b]}^{2}$ tabel dengan derajat bebas $(d b)$ adalah $K$ dikurangi banyak parameter pada model atau $p$-value dari statistik uji $Q$ lebih besar dari nilai $\alpha$, maka terima $H_{0}$ yang artinya residual memenuhi asumsi white noise.

Uji Lagrange Multiplier adalah pengujian untuk mengetahui keberadaan ARCH atau keberadaan heteroskedastisitas dalam runtun waktu. Langkah pertama dari uji ini adalah mengestimasi model ARIMA dari data dan mendapatkan errornya. Langkah selanjutnya dilakukan dengan meregresikan error kuadrat dengan menggunakan konstanta dan nilai error sampai lag ke- $m, \varepsilon_{t-1}^{2}, \varepsilon_{t-2}^{2}, \ldots, \varepsilon_{t-m}^{2}$ sehingga membentuk persamaan regresi sebagai berikut:

$$
\varepsilon_{t}^{2}=\alpha_{0}+\alpha_{1} \varepsilon_{t-1}^{2}+\cdots+\alpha_{m} \varepsilon_{t-m}^{2} ; t=m+1, \ldots, T
$$

Nilai $m$ dapat ditentukan dengan melihat plot PACF residual kuadrat (Tsay, 2005). Hasil regresi ini akan menghasilkan nilai yang akan digunakan untuk menguji hipotesis berikut:

1. Hipotesis:

$H_{0}: \alpha_{1}=\cdots=\alpha_{m}=0$ (tidak terdapat unsur $A R C H$ ) vs $H_{1}:$ minimal ada satu $\alpha_{m} \neq 0$ (terdapat unsur $A R C H$.

2. Statistik Uji:

$$
F=\frac{\left(S S R_{0}-S S R_{1}\right) / m}{S S R_{1} /(T-2 m-1)}
$$


dengan $S S R_{0}=\sum_{t=m+1}^{T}\left(\varepsilon_{t}^{2}-\bar{\omega}\right)^{2}, S S R_{1}=\sum_{m+1}^{T} \hat{\varepsilon}_{t}^{2}, \bar{\omega}$ adalah rata-rata sampel dari $\varepsilon_{t}^{2}$ dengan $\bar{\omega}=\frac{1}{n}\left(\sum_{t-1}^{T} \varepsilon_{t}^{2}\right)$, dan $\hat{\varepsilon}_{t}$ adalah error kuadrat terkecil.

3. Kriteria keputusan: Apabila $F>\chi_{m}^{2}(\alpha)$ atau nilai $p$-value dari $F$ lebih kecil dari $\alpha$, maka $H_{0}$ ditolak yang mengindikasikan error data memiliki efek $\mathrm{ARCH} / \mathrm{GARCH}$ atau bersifat heteroskedastisitas.

\section{Model Generalized Autoregressive Conditional Heteroscedasticity (GARCH)}

Model GARCH $(p, q)$ memiliki persamaan umum sebagai berikut [13].

$$
\sigma_{t}^{2}=\omega+\sum_{i=1}^{q} \beta_{i} \sigma_{t-i}^{2}+\sum_{j=1}^{p} \alpha_{j} \varepsilon_{t-j}^{2}
$$

dengan $p \geq 0, q>0, \omega>0, \alpha_{\mathrm{i}} \geq 0$, untuk $i=1, \ldots, \mathrm{q}$, dan $\beta_{j} \geq 0$, untuk $j=1, \ldots, p$.

Diasumsikan semua parameter adalah positif. Bila $p=q=1$, maka diperoleh estimator GARCH $(1,1)$ dengan masing-masing distribusi adalah normal standar $(\mathrm{GARCH}-\mathrm{n})$ atau Student- $t$ standar $(\mathrm{GARCH}-\mathrm{t})$, maka model didefinisikan sebagai berikut:

$$
\begin{gathered}
r_{t}=\mu+\varepsilon_{t} \\
\varepsilon_{t}=z_{t} \sigma_{t} \\
\sigma_{t}^{2}=\omega+\alpha_{1} \varepsilon_{t-1}^{2}+\beta_{1} \sigma_{t-1}^{2}
\end{gathered}
$$

\section{Uji Dependensi}

Dalam kondisi hubungan non linear antar variabel, korelasi Kendall Tau dapat digunakan sebagai ukuran dependensi alternatif (Matteis, 2001). Uji korelasi Tau Kendall dilakukan dengan hipotesis yang digunakan adalah:

$H_{0}: \tau=0$ (dua variabel independen) vs $H_{1}: \tau \neq 0$ (dua variabel tidak independen)

Statistik Uji:

$$
Z=\sqrt{\frac{9 n(n-1)}{2(2 n+5)}}|\tau|
$$

Dengan

$$
\tau=\frac{c-d}{c+d}=\frac{c-d}{\left(\begin{array}{l}
n \\
2
\end{array}\right)}
$$

$c$ menyatakan banyak pasangan konkordan dan $d$ menyatakan banyak pasangan diskordan dengan kriteria keputusan apabila $Z>Z_{\frac{\alpha}{2}}$ maka $H_{0}$ ditolak.

\section{Copula}

Copula merupakan suatu fungsi distribusi multivariat dengan fungsi distribusi marginalnya (univariat) adalah uniform standar [0,1] (Nelson, 2006). Fungsi copula memiliki konsep sebagai alat untuk mempelajari kebergantungan tak linear antara kejadian dalam kasus multivariat. Copula semakin banyak digunakan pada pemodelan distribusi multivariat karena tidak memerlukan asumsi normalitas pada marginalnya sehingga cukup fleksibel dalam berbagai data terutama untuk data finansial yang tidak memenuhi sifat-sifat distribusi normal.

Pada umumnya keluarga copula yang sering digunakan terdiri atas Copula Elliptical dan Copula Archimedean. Pada penelitian ini keluarga copula yang digunakan adalah Copula Archimedean, yaitu Copula Clayton, Gumbel, dan Frank, sehingga fungsi Copula Archimedean didefinisikan sebagai berikut. 
1. Copula Clayton

Fungsi generator Copula Clayton adalah:

$$
\varphi(u)=u^{-\gamma}-1
$$

sehingga fungsi copula clayton berdimensi dua adalah:

$$
C^{\text {Clay }}\left(u_{1}, u_{2}\right)=\left(u_{1}^{-\gamma}+u_{2}^{-\gamma}-1\right)^{-\frac{1}{\gamma}}
$$

dengan $\gamma \in[-1, \infty) \backslash\{0\}$.

2. Copula Gumbel

Fungsi generator dari Copula Gumbel adalah:

$$
\varphi(u)=(-\ln u)^{\gamma}
$$

sehingga fungsi Copula Gumbel berdimensi dua adalah:

$$
C^{G u}\left(u_{1}, u_{2}\right)=\exp \left\{-\left[\left(-\ln u_{1}\right)^{\gamma}+\left(-\ln u_{2}\right)^{\gamma}\right]^{\frac{1}{\gamma}}\right\}
$$

dengan $\gamma \in[1, \infty)$.

3. Copula Frank

Fungsi generator dari Copula Frank adalah:

$$
\varphi(u)=\ln \left[\frac{e^{-\gamma u}-1}{e^{-\gamma}-1}\right]
$$

sehingga fungsi copula clayton berdimensi dua adalah:

dengan $\gamma \in \mathbb{R}\{0\}$.

$$
C^{F r}\left(u_{1}, u_{2}\right)=-\frac{1}{\gamma} \ln \left(1+\frac{\left(e^{\left(-\gamma u_{1}\right)}-1\right)\left(e^{-\gamma u_{2}}-1\right)}{\left(e^{-\gamma}-1\right)}\right)
$$

\section{Vine Copula}

Konstruksi dari fungsi distribusi multi-dimensi menjadi semakin rumit ketika dimensinya semakin bertambah. Vine Copula atau yang dikenal juga dengan Pair copula (copula berpasangan) memberikan cara yang lebih fleksibel dalam mengkonstruksi distribusi multivariat. Ide pokok dari pair copula yaitu menjelaskan bahwa copula multivariat dapat didekomposisikan menjadi pasangan copula bivariate.

Vine copula diterapkan jika sedikitnya 3 dimensi peubah acak yang ingin diketahui fungsi bersamanya. Dengan vine copula, fungsi densitas d dimensi dapat diperoleh dengan melakukan dekomposisi sehingga diperoleh hasil kali dari densitas marginalnya dengan densitas copula berpasangan. Dalam melakukan pemilihan model yang tepat haruslah menentukan struktur (tree), keluarga copula, dan menduga parameter copula. Untuk menentukan struktur (tree), pada penelitian ini dibahas 2 jenis vine copula, yaitu C-vine copula, dan D-vine copula.

\section{D-Vine Copula}

D-vine copula memiliki struktur grafik dengan setiap tree merupakan suatu path. Jika terdapat $d$ dimensi, maka banyaknya tree adalah $d-1$. Misal, untuk 3 dimensi, maka diperoleh dua tree sebagai berikut: 


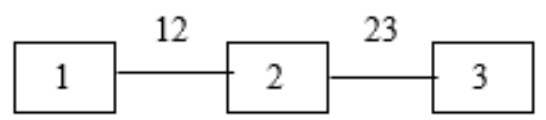

(a)

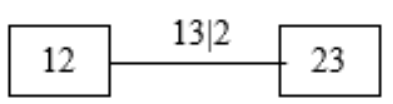

(b)

Gambar 1. D-Vine Copula 3 Dimensi (a) Pohon 1 (b) Pohon 2

Sehingga fungsi densitas D-Vine menurut dekomposisi pada Gambar 1 adalah:

$$
\begin{aligned}
f\left(x_{1}, x_{2}, x_{3}\right)= & \mathrm{f}_{1}\left(\mathrm{x}_{1}\right) \cdot \mathrm{f}_{2}\left(\mathrm{x}_{2}\right) \cdot \mathrm{f}_{3}\left(\mathrm{x}_{3}\right) \mathrm{c}_{12}\left(\mathrm{~F}_{1}\left(\mathrm{x}_{1}\right), \mathrm{F}_{2}\left(\mathrm{x}_{2}\right)\right) \\
& . c_{23}\left(F_{2}\left(x_{2}\right), F_{3}\left(x_{3}\right)\right) \cdot c_{13 \mid 2}\left(F\left(x_{1} \mid x_{2}\right), F\left(x_{3} \mid x_{2}\right)\right)
\end{aligned}
$$

Secara umum fungsi densitas, D-Vine berdimensi $d$ adalah

$$
\begin{aligned}
f\left(x_{1}, \ldots, x_{d}\right)= & \prod_{\mathrm{k}=1}^{d} f\left(x_{\mathrm{k}}\right) \prod_{\mathrm{j}=1}^{d-1} \prod_{i=1}^{d-\mathrm{j}} c_{i, \mathrm{i}+\mathrm{j} \mid \mathrm{i}+1, \ldots, \mathrm{i}+\mathrm{j}-1} \\
& \cdot\left(F\left(x_{i} \mid x_{i+1}, \ldots, x_{i+j-1}\right) F\left(x_{i+j} \mid x_{i+1}, \ldots, x_{i+j-1}\right)\right)
\end{aligned}
$$

\section{C-Vine Copula}

C-vine copula memiliki struktur grafik (tree) dengan setiap tree memiliki node yang unik yaitu yang dihubungkan ke seluruh node. Jika terdapat d dimensi, maka banyaknya tree adalah d1. Misal, untuk 3 dimensi, maka diperoleh 2 tree sebagai berikut:

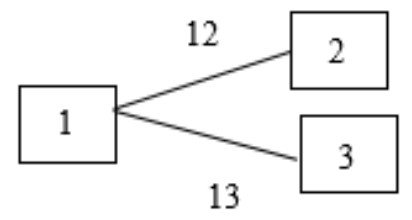

(a)

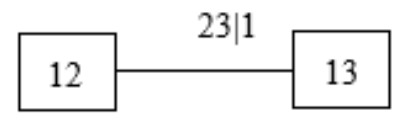

(b)

Gambar 2. C-Vine Copula 3 dimensi (a) Pohon 1; (b) Pohon 2.

Dari Gambar 2 dapat dilihat bahwa variabel 1 bertindak sebagai variabel kunci dalam C-Vine yang berinteraksi dengan seluruh variabel dalam data. Oleh karena itu, pembentukan C-Vine akan menguntungkan ketika suatu variabel telah diketahui sebagai variabel kunci. Selanjutnya variabel kunci ini menjadi akar dari struktur C-Vine (Liu, 2011). 
Sehingga fungsi densitas C-Vine menurut dekomposisi pada Gambar 2 adalah:

$$
\begin{aligned}
f\left(x_{1}, x_{2}, x_{3}\right)= & \mathrm{f}_{1}\left(\mathrm{x}_{1}\right) \cdot \mathrm{f}_{2}\left(\mathrm{x}_{2}\right) \cdot \mathrm{f}_{3}\left(\mathrm{x}_{3}\right) \mathrm{c}_{12}\left(\mathrm{~F}_{1}\left(\mathrm{x}_{1}\right), \mathrm{F}_{2}\left(\mathrm{x}_{2}\right)\right) \\
& . c_{13}\left(F_{1}\left(x_{1}\right), F_{3}\left(x_{3}\right)\right) \cdot c_{23 \mid 1}\left(F_{2}\left(x_{2} \mid x_{1}\right), F_{3}\left(x_{3} \mid x_{1}\right)\right)
\end{aligned}
$$

Secara umum fungsi densitas, C-Vine berdimensi $d$ adalah

$$
f\left(x_{1}, \ldots, x_{d}\right)=\prod_{\mathrm{k}=1}^{d} f\left(x_{\mathrm{k}}\right) \prod_{j=1}^{d-1} \prod_{i=1}^{d-\mathrm{j}} c_{j, j+i \mid 1, \ldots, j-1}\left(F\left(x_{j} \mid x_{1}, \ldots, x_{j-1}\right), F\left(x_{j+i} \mid x_{1}, \ldots, x_{j-1}\right)\right)
$$

\section{Estimasi Parameter}

Estimasi parameter copula dapat diperoleh dengan menggunakan metode maksimum likelihood (MLE). Pada bagian ini akan dijelaskan estimasi parameter dari densitas C-Vine dan D-Vine dengan MLE. Asumsikan terdapat $d$ variabel pada $T$ titik waktu, estimasi parameter dapat dilakukan secara simultan terhadap distribusi marginal dan pasangan copula metode MLE. Namun, komputasi dengan metode ini akan semakin kompleks seiring bertambahnya dimensi variabel (Liu, 2011). Oleh karena itu, pada pembahasan ini digunakan metode Inference Function for Margins (IFM) dimana estimasi parameter dilakukan dalam dua tahap dan dasar dari tiap tahapnya menggunakan pendekatan log likelihood (Joe, 1996). Pada tahap pertama metode IFM, dilakukan estimasi parameter dari distribusi marginal.

Berdasarkan densitas C-Vine dan D-Vine yang telah dibentuk pada persamaan (26) dan (28) maka dapat diperoleh fungsi log likelihood untuk C-Vine yaitu:

$$
\begin{gathered}
l_{C-\text { Vine }}(x ; \gamma)=\sum_{k=1}^{3} \sum_{t=1}^{T} \log \left(f\left(x_{k}\right)\right) \\
+\sum_{j=1}^{2} \sum_{i=1}^{3-j} \sum_{t=1}^{T} \log \left(c_{j, j+1 \mid 1, \ldots, j-1}\left(F\left(x_{j, t} \mid x_{1, t}, \ldots, x_{j-1, t}\right), F\left(x_{j+i, t} \mid x_{1, t}, \ldots, x_{j^{\prime}-1, t}\right)\right)\right)
\end{gathered}
$$

dan fungsi log likelihood untuk D-Vine yaitu:

$$
l_{\text {C-Vine }}(x ; \gamma)=\sum_{k=1}^{3} \sum_{t=1}^{T} \log \left(f\left(x_{k}\right)\right)
$$

$+\sum_{j=1}^{2} \sum_{i=1}^{3-j} \sum_{t=1}^{T} \log \left(c_{i, i+j \mid i+1, \ldots, i+j-1}\left(\left(F\left(x_{i, t} \mid x_{i+1, t}, \ldots, x_{i+j-1, t}\right), F\left(x_{i+j, t} \mid x_{i+1, t}, \ldots, x_{i+j-1, t}\right)\right)\right)\right.$

\section{Value at Risk (VaR)}

VaR merupakan alat ukur yang dapat menghitung besarnya kerugian terburuk yang dapat terjadi dengan mengetahui posisi asset, tingkat kepercayaan akan terjadinya risiko, dan jangka waktu penempatan asset (time horizon) (Jorian, 2002).

VaR pada tingkat kepercayaan $(1-\alpha)$ dapat dituliskan sebagai berikut:

$$
\operatorname{VaR}=W_{0} Z_{1-\alpha} \sigma(R p)
$$

dengan $W_{0}$ merupakan nilai awal investasi, dan $\sigma\left(R_{p}\right)$ adalah standar deviasi return. 


\section{Metode Penelitian}

\section{Sumber Data}

Pada penelitian ini digunakan data harga penutupan (closed price) saham harian mulai 26 Agustus 2013 sampai dengan 20 November 2017 yang terdiri dari 1038 observasi dan diperoleh dari situs www.yahoo-finance.com khususnya saham sektor perbankan LQ45 yaitu, BBNI, BBRI, dan BMRI. Sedangkan bobot yang digunakan dalam pembentukan portofolio pada penelitian ini diasumsikan sama untuk setiap saham yaitu $\frac{1}{n^{\prime}}$ sehingga menurut persamaan (2) diperoleh persamaan return portofolio sebagai berikut:

$$
R_{p}=\frac{1}{3} R_{B B N I}+\frac{1}{3} R_{B B R I}+\frac{1}{3} R_{B M R I}
$$

\section{Langkah-Langkah Analisis}

Langkah-langkah dalam menentukan estimasi Value at Risk $(\mathrm{VaR})$ dengan menggunakan metode GARCH-Vine Copula dikembangkan dari Flow Chart perhitungan VaR menggunakan metode Elliptical Copula dari Renggani dkk (2017) sebagai berikut:

1. Menghitung return harga saham.

2. Mendeskripsikan dan mengidentifikasi karakteristik data.

3. Pemodelan Marginal dengan GARCH

a. Melakukan pengujian kestasioneran data. Setelah data dinyatakan stasioner terhadap mean dan varians, dapat dilanjutkan dengan menentukan ordo model ARIMA menggunakan plot ACF dan PACF, kemudian menentukan model ARIMA terbaik dengan kriteria AIC.

b. Melakukan pengujian efek $\mathrm{ARCH}$ terhadap residual ARIMA untuk mengetahui ada tidaknya heteroskedastisitas.

c. Membentuk model marginal GARCH menggunakan metode maksimum likelihood untuk mengatasi masalah heteroskedastisitas kemudian menggunakan distribusi Student-t pada residual GARCH dan mengidentifikasi struktur kebergantungan model marginal.

4. Membentuk distribusi gabungan dari model marginal ketiga saham dengan Vine Copula.

a. Menentukan dekomposisi Vine Copula yang digunakan.

b. Mengestimasi parameter Vine Copula

c. Memilih copula terbaik berdasarkan kriteria AIC.

5. Melakukan estimasi VaR.

6. Membuat kesimpulan hasil analisis VaR berdasarkan pemilihan model copula terbaik.

\section{Hasil dan Pembahasan}

\section{Karakteristik Data}

Sebelum dilakukan estimasi nilai $\mathrm{VaR}$, terlebih dahulu dilakukan analisa deskriptif untuk mengetahui karakteristik masing-masing saham yang dianalisa yaitu BBNI, BBRI, dan BMRI. Dalam menganalisis keseluruhan data perangkat lunak yang digunakan adalah perangkat lunak pemrograman $R$ 3.3.1.

Gambar 3 menunjukkan bahwa nilai return saham menunjukkan adanya variabilitas data yang relatif tinggi pada suatu waktu dan terjadi kecenderungan yang sama dalam kurun waktu selanjutnya dan sebaliknya. Fenomena ini disebut dengan volatility clustering yang menandakan adanya kasus heterokedastisistas. Setelah melihat pola penyebaran data, analisis statistik deskriptif juga dilakukan untuk melihat karakteristik data return masing-masing aset. Tabel 1 menyajikan ringkasan deskripsi statistik dari data return indeks saham BBNI, BBRI, dan BMRI. 


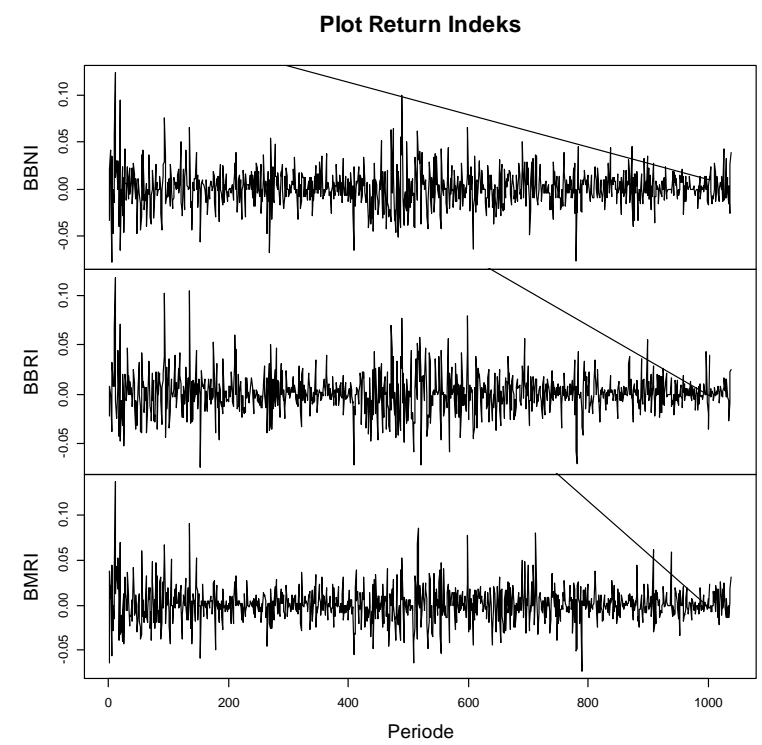

Gambar 3. Plot time series return saham BBNI, BBRI, dan BMRI.

Tabel 1. Analisis deskriptif saham BBNI, BBRI, dan BMRI.

\begin{tabular}{lrrr}
\hline Statistik & BBNI & BBRI & BMRI \\
\hline Mean & 0,00092 & 0,00174 & 0,000893 \\
Std. Deviasi & 0,01950 & 0,019756 & 0,019132 \\
Skewness & 0,37595 & 0,449172 & 0,614406 \\
Kurtosis & 3,62979 & 3,720852 & 4,502484 \\
Minimum & $-0,0779$ & $-0,073710$ & $-0,073395$ \\
Maksimum & 0,12329 & 0,118056 & 0,136691 \\
\hline
\end{tabular}

Tabel 1 menunjukkan ketiga return saham memiliki nilai rata-rata return bernilai positif yang berarti ketiga saham ini akan cenderung memberikan keuntungan kepada investor. Nilai varians tertinggi dimiliki oleh saham BBRI yaitu sebesar 0,0198, yang menunjukkan bahwa saham BBRI memiliki potensi risiko paling besar dibandingkan saham lainnya.

Nilai skewness (nilai kemencengan) pada ketiga indeks saham bernilai positif, yang menunjukkan distribusi data return tidak simetris atau memiliki ekor kanan yang lebih panjang dibanding ekor kiri (long right tai). Nilai kurtosis (keruncingan) pada ketiga saham memiliki nilai lebih dari tiga, hal ini menunjukkan kurva data return ketiga saham tersebut memiliki kurva leptokurtic (bagian tengah distribusi data memiliki puncak meruncing). Kedua hal diatas dapat menjelaskan adanya dugaan data return ketiga saham tidak berdistribusi normal. Selanjutnya untuk menunjukkan ketidaknormalan distribusi, dilakukan pengujian distribusi normal terhadap return saham BBNI, BBRI, dan BMRI dengan uji Kolmogorov Smirnov dengan hasil sebagai berikut.

Tabel 2. Pengujian distribusi normal.

\begin{tabular}{lccc}
\hline Saham & $\boldsymbol{D}_{\text {hit }}$ & $\boldsymbol{p}$-value & Keputusan \\
\hline BBNI & 0,4728 & $<2,2 \times 10^{-16}$ & Tolak $H_{0}$ \\
BBRI & 0,4727 & $<2,2 \times 10^{-16}$ & Tolak $H_{0}$ \\
BMRI & 0,4738 & $<2,2 \times 10^{-16}$ & Tolak $H_{0}$ \\
\hline
\end{tabular}

Pada Tabel 2 menunjukkan apabila nilai $\mathrm{p}$-value ketiga return saham kurang dari nilai $\alpha$ sehingga $H_{0}$ ditolak. Jadi, pada tingkat signifikansi 0,05 dapat disimpulkan bahwa ketiga return saham tidak berdistribusi normal. 


\section{Pemodelan ARIMA}

Dalam pemodelan ARIMA, langkah pertama yang dilakukan adalah memeriksa kestasioneran data. Gambar 3 menunjukkan bahwa secara visual data telah stasioner dalam rata-rata karena cenderung berada di sekitar nilai rata-rata. Tren data pada Gambar 3 mengindikasikan data tersebut bersifat stasioner. Setelah asumsi kestasioneran terpenuhi, maka selanjutnya dilakukan pendugaan model ARIMA. Penentuan orde AR dan orde MA dalam identifikasi model menggunakan plot fungsi autoregresif (ACF) dan fungsi autoregresif parsial (PACF). Tabel 3 menunjukkan model dugaan ARIMA beserta estimasi parameter dari masing-masing saham telah signifikan. Setelah itu, dilakukan uji white noise.

Tabel 3. Estimasi dan uji signifikansi parameter model ARIMA.

\begin{tabular}{|c|c|c|c|c|}
\hline Saham & Model & Parameter & Estimasi & $\mathrm{p}$-value \\
\hline \multirow{3}{*}{$\mathrm{BBNI}$} & $\begin{array}{l}\text { ARIMA } \\
(1,0,2)\end{array}$ & $\begin{array}{l}\phi_{1} \\
\theta_{1} \\
\theta_{2}\end{array}$ & $\begin{array}{r}0,8108 \\
-0,7640 \\
-0,0772\end{array}$ & $\begin{array}{r}2,418 \mathrm{e}-14 \\
2,679 \mathrm{e}-12 \\
0,01327\end{array}$ \\
\hline & $\begin{array}{l}\text { ARIMA } \\
(2,0,1)\end{array}$ & $\begin{array}{l}\phi_{1} \\
\phi_{2} \\
\theta_{1} \\
\end{array}$ & $\begin{array}{r}0,8908 \\
-0,0777 \\
-0,8428 \\
\end{array}$ & $\begin{array}{r}<2 \mathrm{e}-16 \\
0,01343 \\
<2 \mathrm{e}-16 \\
\end{array}$ \\
\hline & $\begin{array}{l}\text { ARIMA } \\
(2,0,2)\end{array}$ & $\begin{array}{l}\phi_{1} \\
\phi_{2} \\
\theta_{1} \\
\theta_{2} \\
\end{array}$ & $\begin{array}{r}-0,0644 \\
-0,9963 \\
0,0605 \\
0,9835 \\
\end{array}$ & $\begin{array}{r}<2,2 \mathrm{e}-16 \\
<2,2 \mathrm{e}-16 \\
1,319 \mathrm{e}-09 \\
<2,2 \mathrm{e}-16 \\
\end{array}$ \\
\hline \multirow{6}{*}{ BBRI } & $\begin{array}{l}\text { ARIMA } \\
(2,0,0) \\
\end{array}$ & $\begin{array}{l}\phi_{1} \\
\phi_{2}\end{array}$ & $\begin{array}{r}0,0862 \\
-0,0894 \\
\end{array}$ & $\begin{array}{l}0,005299 \\
0,003873\end{array}$ \\
\hline & $\begin{array}{l}\text { ARIMA } \\
(0,0,2)\end{array}$ & $\begin{array}{l}\theta_{1} \\
\theta_{2}\end{array}$ & $\begin{array}{r}0,0815 \\
-0,0852\end{array}$ & $\begin{array}{l}0,009157 \\
0,008746\end{array}$ \\
\hline & $\begin{array}{l}\text { ARIMA } \\
(1,0,1) \\
\end{array}$ & $\begin{array}{l}\phi_{1} \\
\theta_{1}\end{array}$ & $\begin{array}{r}-0,4247 \\
0,5213 \\
\end{array}$ & $\begin{array}{l}0,01736 \\
0,00183 \\
\end{array}$ \\
\hline & $\begin{array}{l}\text { ARIMA } \\
(1,0,2)\end{array}$ & $\begin{array}{l}\phi_{1} \\
\theta_{1} \\
\theta_{2}\end{array}$ & $\begin{array}{r}0,7860 \\
-0,7073 \\
-0,1432 \\
\end{array}$ & $\begin{array}{r}<2,2 \mathrm{e}-16 \\
<2,2 \mathrm{e}-16 \\
1,365 \mathrm{e}-05\end{array}$ \\
\hline & $\begin{array}{l}\text { ARIMA } \\
(2,0,1)\end{array}$ & $\begin{array}{l}\phi_{1} \\
\phi_{2} \\
\theta_{1} \\
\end{array}$ & $\begin{array}{r}0,9310 \\
-0,1308 \\
-0,8594 \\
\end{array}$ & $\begin{array}{r}<2,2 \mathrm{e}-16 \\
3,579 \mathrm{e}-05 \\
<2,2 \mathrm{e}-16 \\
\end{array}$ \\
\hline & $\begin{array}{l}\text { ARIMA } \\
(3,0,4)\end{array}$ & $\begin{array}{l}\phi_{1} \\
\phi_{2} \\
\phi_{3} \\
\theta_{1} \\
\theta_{2} \\
\theta_{3} \\
\theta_{4} \\
\end{array}$ & $\begin{array}{r}0,9345 \\
0,9386 \\
-0,9242 \\
-0,8544 \\
-1,0583 \\
0,8364 \\
0,1232\end{array}$ & $\begin{array}{r}<2,2 \mathrm{e}-16 \\
<2,2 \mathrm{e}-16 \\
<2,2 \mathrm{e}-16 \\
<2,2 \mathrm{e}-16 \\
<2,2 \mathrm{e}-16 \\
<2,2 \mathrm{e}-16 \\
0,0004821\end{array}$ \\
\hline \multirow{3}{*}{ BMRI } & $\begin{array}{l}\text { ARIMA } \\
(1,0,2)\end{array}$ & $\begin{array}{l}\phi_{1} \\
\theta_{1} \\
\theta_{2}\end{array}$ & $\begin{array}{r}0,6570 \\
-0,6352 \\
-0,1115 \\
\end{array}$ & $\begin{array}{l}0,0001105 \\
0,0001842 \\
0,0014347\end{array}$ \\
\hline & $\begin{array}{l}\text { ARIMA } \\
(2,0,1)\end{array}$ & $\begin{array}{l}\phi_{1} \\
\phi_{2} \\
\theta_{1}\end{array}$ & $\begin{array}{r}0,7306 \\
-0,1084 \\
-0,7102 \\
\end{array}$ & $\begin{array}{l}0,003358 \\
0,005687 \\
0,004810\end{array}$ \\
\hline & $\begin{array}{l}\text { ARIMA } \\
(4,0,1)\end{array}$ & $\begin{array}{l}\phi_{1} \\
\phi_{2} \\
\phi_{3} \\
\phi_{4} \\
\theta_{1}\end{array}$ & $\begin{array}{r}-0,6343 \\
-0,0832 \\
-0,1280 \\
-0,0830 \\
0,6590\end{array}$ & $\begin{array}{l}0,004278 \\
0,025435 \\
0,002557 \\
0,008732 \\
0,002862\end{array}$ \\
\hline
\end{tabular}


Tabel 4. Uji White Noise model dugaan ARIMA.

\begin{tabular}{ccccccc}
\hline \multirow{2}{*}{ Saham } & \multirow{2}{*}{ Model } & \multicolumn{5}{c}{ Lag } \\
\cline { 2 - 7 } & & $\mathbf{6}$ & $\mathbf{1 2}$ & $\mathbf{1 8}$ & $\mathbf{2 4}$ & $\mathbf{3 6}$ \\
\hline \multirow{3}{*}{ BBNI } & ARIMA $(1,0,2)$ & 0,70 & 0,71 & 0,53 & 0,50 & 0,45 \\
\cline { 2 - 7 } & ARIMA $(2,0,1)$ & 0,71 & 0,71 & 0,52 & 0,49 & 0,45 \\
\cline { 2 - 7 } & ARIMA $(2,0,2)$ & 0,20 & 0,40 & 0,42 & 0,26 & 0,59 \\
\hline \multirow{5}{*}{ BBRI } & ARIMA $(2,0,0)$ & 0,37 & 0,33 & 0,09 & 0,09 & 0,06 \\
\cline { 2 - 7 } & ARIMA $(0,0,2)$ & 0,35 & 0,33 & 0,08 & 0,09 & 0,06 \\
\cline { 2 - 7 } & ARIMA $(1,0,1)$ & 0,21 & 0,24 & 0,07 & 0,08 & 0,08 \\
\cline { 2 - 7 } & ARIMA $(1,0,2)$ & 0,98 & 0,78 & 0,42 & 0,38 & 0,26 \\
\cline { 2 - 7 } & ARIMA $(2,0,1)$ & 0,91 & 0,71 & 0,36 & 0,34 & 0,23 \\
\cline { 2 - 7 } BMRI & ARIMA $(3,0,4)$ & 0,67 & 0,50 & 0,22 & 0,21 & 0,38 \\
\cline { 2 - 7 } & ARIMA $(1,0,2)$ & 0,09 & 0,46 & 0,76 & 0,52 & 0,22 \\
\cline { 2 - 7 } & ARIMA $(2,0,1)$ & 0,89 & 0,44 & 0,74 & 0,49 & 0,19 \\
\hline & ARIMA (4,0,1) & 0,97 & 0,55 & 0,84 & 0,59 & 0,25 \\
\hline
\end{tabular}

Tabel 4 menunjukkan p-value dari masing-masing model dugaan ARIMA lebih besar dari 0,05. Oleh karena itu, $H_{0}$ diterima dan dapat disimpulkan bahwa residual model dugaan ARIMA pada ketiga saham memenuhi asumsi White Noise. Setelah itu, dilakukan pemilihan terbaik model dugaan ARIMA.

Tabel 5. Pemilihan model terbaik pada model ARIMA.

\begin{tabular}{lll}
\hline Saham & Model & AIC \\
\hline \multirow{3}{*}{ BBNI } & $\operatorname{ARIMA}(1,0,2)$ & $-5226,74$ \\
\cline { 2 - 3 } & $\operatorname{ARIMA}(2,0,1)$ & $-5226,85$ \\
\cline { 2 - 3 } & $\operatorname{ARIMA}(2,0,2)$ & $-5230,41$ \\
\hline \multirow{3}{*}{ BBRI } & $\operatorname{ARIMA}(2,0,0)$ & $-5208,97$ \\
\cline { 2 - 3 } & $\operatorname{ARIMA}(0,0,2)$ & $-5208,84$ \\
\cline { 2 - 3 } & $\operatorname{ARIMA}(1,0,1)$ & $-5205,88$ \\
\hline \multirow{3}{*}{ BMRI } & $\operatorname{ARIMA}(1,0,2)$ & $-5215,3$ \\
\cline { 2 - 3 } & $\operatorname{ARIMA}(2,0,1)$ & $-5214,16$ \\
\cline { 2 - 3 } & $\operatorname{ARIMA}(1,0,4)$ & $-5214,02$ \\
\cline { 2 - 3 } & $\operatorname{ARIMA}(2,0,1)$ & $-5275,98$ \\
\cline { 2 - 3 } & $\operatorname{ARIMA}(4,0,1)$ & $-5275,66$ \\
\hline
\end{tabular}

Pada Tabel 5 menunjukkan nilai AIC dari masing-masing model dugaan dengan mempertimbangkan nilai AIC terkecil, sehingga diperoleh model terbaik untuk saham BBNI adalah ARIMA $(2,0,1)$, saham BBRI adalah ARIMA $(1,0,2)$, dan saham BMRI adalah ARIMA $(4,0,2)$.

\section{Uji Efek ARCH}

Uji Lagrange Multiplier (LM) digunakan untuk mengetahui ada tidaknya efek ARCH/GARCH pada residual model ARIMA. Hasil pengujiannya disajikan pada Tabel 6.

Tabel 6. Uji LM pada residual BBNI, BBRI, dan BMRI

\begin{tabular}{ccccccc}
\hline \multirow{2}{*}{ Order } & \multicolumn{2}{c}{ BBNI } & \multicolumn{2}{c}{ BBRI } & \multicolumn{2}{c}{ BMRI } \\
\cline { 2 - 7 } & LM & p-value & LM & p-value & LM & p-value \\
\hline 4 & 933,1 & 0 & 967 & 0 & 1090 & 0 \\
8 & 342,2 & 0 & 421 & 0 & 429 & 0 \\
12 & 168,1 & 0 & 230 & 0 & 185 & 0 \\
16 & 118,6 & 0 & 166 & 0 & 140 & 0 \\
20 & 115,9 & $6,66 \mathrm{e}-16$ & 146 & 0 & 126 & 0 \\
24 & 91,6 & $3,88 \mathrm{e}-10$ & 119 & $7,11 \mathrm{e}-15$ & 104 & $2,51 \mathrm{e}-12$ \\
\hline
\end{tabular}


Berdasarkan Tabel 6 diperoleh nilai $p$-value ketiga saham pada setiap order memiliki nilai lebih dari $\alpha$ yaitu 0,05, maka dapat disimpulkan bahwa terdapat efek $\mathrm{ARCH}$ pada residual kuadrat $\left(\varepsilon^{2}\right)$ dan ketidakstabilan varians pada ketiga return saham, sehingga dapat dilanjutkan dengan menggunakan pemodelan GARCH.

\section{Pemodelan GARCH}

Dalam penelitian ini digunakan model $\mathrm{GARCH}(1,1)$ untuk mengatasi masalah heteroskedastisitas dengan residual yang disyarati dengan inovasi distribusi Student-t. Hasil estimasi model GARCH untuk saham BBNI, BBRI, dan BMRI disajikan pada tabel 7.

Tabel 7. Estimasi dan uji signifikansi parameter model GARCH.

\begin{tabular}{ccccc}
\hline Saham & Model & Parameter & Estimasi & p-value \\
\hline \multirow{3}{*}{ BBNI } & GARCH & $\alpha_{1}$ & 0,1224 & 0,000691 \\
& $(1,1)$ & $\beta_{1}$ & 0,8362 & $<2 \mathrm{e}-16$ \\
& $v$ & 4,801 & $4,66 \mathrm{e}-10$ \\
\hline \multirow{3}{*}{ BBRI } & GARCH & $\alpha_{1}$ & 0,1316 & 0,00521 \\
& $(1,1)$ & $\beta_{1}$ & 0,8794 & $<2 \mathrm{e}-16$ \\
& & $v$ & 3,590 & $1,33 \mathrm{e}-15$ \\
\hline \multirow{3}{*}{ BMRI } & \multirow{2}{*}{ GARCH } & $\alpha_{1}$ & 0,2185 & 0,000178 \\
& $(1,1)$ & $\beta_{1}$ & 0,7525 & $<2 \mathrm{e}-16$ \\
& & $v$ & 3,904 & $1,29 \mathrm{e}-14$ \\
\hline
\end{tabular}

Pada tabel 7 dapat dilihat bahwa pada model GARCH $(1,1)$ masing-masing saham memiliki nilai p-value yang lebih kecil dari $\alpha=0,05$, sehingga dapat disimpulkan bahwa model GARCH-t $(1,1)$ pada saham BBNI, BBRI, dan BMRI signifikan.

\section{Pemodelan Vine Copula}

Setelah memodelkan masing-masing return saham dengan model $\mathrm{GARCH}$, untuk memodelkan dengan Vine Copula langkah selanjutnya adalah menyelidiki dependensi diantara ketiga pasangan variabel. Untuk mengetahui dependensi antar variabel, dilakukan pengujian dependensi dengan menggunakan uji Kendall Tau. Berikut adalah hasil pengujian dependensi antar saham.

Tabel 8. Uji kebergantungan saham.

\begin{tabular}{lccc}
\hline Kombinasi Saham & Korelasi & $\mathbf{Z}$ & p-value \\
\hline BBNI dan BBRI & 0,3663 & 17,671 & $<2,2 \mathrm{e}-16$ \\
BBNI dan BMRI & 0,3528 & 17,02 & $<2,2 \mathrm{e}-16$ \\
BBRI dan BMRI & 0,4201 & 20,266 & $<2,2 \mathrm{e}-16$ \\
\hline
\end{tabular}

Tabel 8 menyajikan hasil pengujian kebergantungan antar saham. Nilai p-value hasil pengujian ini pada sebesar <2,2e-16 yang artinya ada kebergantungan antar saham-saham tersebut.

Setelah dinyatakan terdapat ketergantungan antar saham-saham, kemudian akan dilakukan estimasi parameter untuk masing-masing copula dengan metode maximum likelihood. Copula yang digunakan adalah C-Vine dan D-Vine Copula dari keluarga Archimedean yaitu Copula Clayton, Gumbel, dan Frank. Estimasi parameter dilakukan dengan prinsip pasangan copula bivariat pada setiap level. Berikut adalah hasil estimasi parameter Vine Copula.

Tabel 9 menunjukkan hasil estimasi parameter C-Vine dan D-Vine Copula dari berbagai model copula. Nilai log likelihood yang dihasilkan oleh dekomposisi C-Vine dan D-Vine cenderung tidak berbeda secara signifikan di setiap keluarga copula. Hal ini dapat menandakan bahwa model yang dihasilkan dengan kedua dekomposisi relatif sama baiknya. Untuk menentukan copula terbaik dalam memodelkan data untuk studi kasus ini, dapat digunakan nilai AIC terkecil dari masing-masing model. Dapat dilihat Frank D-Vine Copula memiliki nilai AIC terkecil yaitu $-1112,63$. Oleh karena itu, dapat disimpulkan bahwa Frank D-Vine Copula adalah copula terbaik yang dapat digunakan untuk memodelkan data dalam kasus ini. 
Tabel 9. Estimasi parameter C-Vine dan D-Vine Copula.

\begin{tabular}{|c|c|c|c|c|}
\hline Vine Copula & Copula & Pair & Parameter & $\mathrm{AIC}$ \\
\hline \multirow{3}{*}{ C-Vine } & Clayton & $\begin{array}{c}1,2 \\
1,3 \\
2,3 ; 1 \\
\end{array}$ & $\begin{aligned} \rho_{12} & =1,55 \\
\rho_{13} & =1,41 \\
\rho_{23 \mid 1} & =0,74\end{aligned}$ & $-971,8$ \\
\hline & Gumbel & $\begin{array}{c}1,2 \\
1,3 \\
2,3 ; 1\end{array}$ & $\begin{aligned} \rho_{12} & =1,96 \\
\rho_{13} & =1,85 \\
\rho_{23 \mid 1} & =1,46\end{aligned}$ & $-1073,2$ \\
\hline & Frank & $\begin{array}{c}1,2 \\
1,3 \\
2,3 ; 1 \\
\end{array}$ & $\begin{aligned} \rho_{12} & =5,62 \\
\rho_{13} & =5,22 \\
\rho_{23 \mid 1} & =3,83\end{aligned}$ & -1120 \\
\hline \multirow{3}{*}{ D-Vine } & Clayton & $\begin{array}{c}1,2 \\
2,3 \\
1,3 ; 2 \\
\end{array}$ & $\begin{aligned} \rho_{12} & =1,55 \\
\rho_{13} & =1,93 \\
\rho_{23 \mid 1} & =0,32\end{aligned}$ & $-1003,2$ \\
\hline & Gumbel & $\begin{array}{c}1,2 \\
2,3 \\
1,3 ; 2\end{array}$ & $\begin{aligned} \rho_{12} & =1,96 \\
\rho_{13} & =2,15 \\
\rho_{23 \mid 1} & =1,20\end{aligned}$ & $-1092,7$ \\
\hline & Frank & $\begin{array}{c}1,2 \\
2,3 \\
1,3 ; 2 \\
\end{array}$ & $\begin{aligned} \rho_{12} & =5,62 \\
\rho_{13} & =6,67 \\
\rho_{23 \mid 1} & =2,17\end{aligned}$ & $-1112,6$ \\
\hline
\end{tabular}

Tabel 9 menunjukkan hasil estimasi parameter C-Vine dan D-Vine Copula dari berbagai model copula. Nilai log likelihood yang dihasilkan oleh dekomposisi C-Vine dan D-Vine cenderung tidak berbeda secara signifikan di setiap keluarga copula. Hal ini dapat menandakan bahwa model yang dihasilkan dengan kedua dekomposisi relatif sama baiknya. Untuk menentukan copula terbaik dalam memodelkan data untuk studi kasus ini, dapat digunakan nilai AIC terkecil dari masing-masing model. Dapat dilihat Frank D-Vine Copula memiliki nilai AIC terkecil yaitu $-1112,63$. Oleh karena itu, dapat disimpulkan bahwa Frank D-Vine Copula adalah copula terbaik yang dapat digunakan untuk memodelkan data dalam kasus ini.

\section{Perhitungan Value at Risk (VaR)}

Model Frank D-Vine Copula digunakan dalam proses pembangkitan data untuk menghitung nilai VaR. Tabel 10 menyajikan hasil perhitungan VaR dengan membangkitkan 1038 data dengan 100 kali pengulangan pada tingkat kepercayaan 90\%, 95\%, dan 99\%.

Tabel 10. Estimasi VaR dengan Vine Copula.

\begin{tabular}{ccc}
\hline Keluarga Copula & Tingkat Kepercayaan & $\begin{array}{c}\boldsymbol{V} \boldsymbol{V a \boldsymbol { R } _ { \boldsymbol { \alpha } }} \\
\text { (Std. Error) }\end{array}$ \\
\hline & $90 \%$ & $\begin{array}{c}0,01856018 \\
(3,909566 \mathrm{e}-05)\end{array}$ \\
\cline { 2 - 3 } D-Vine Frank & $95 \%$ & $\begin{array}{c}0,02562304 \\
(5,475796 \mathrm{e}-05)\end{array}$ \\
\cline { 2 - 3 } & $99 \%$ & $\begin{array}{c}0,0448919 \\
(0,0001442081)\end{array}$ \\
\hline
\end{tabular}

Tabel 10 menunjukkan pada tingkat kepercayaan 99\% nilai VaR portofolio lebih besar dibanding nilai VaR pada tingkat kepercayaan $90 \%$ dan $95 \%$ yaitu sebesar $4,49 \%$ dari dana investasi. Berdasarkan hal tersebut dapat disimpulkan bahwa semakin besar tingkat kepercayaan yang digunakan, estimasi nilai VaR yang dihasilkan juga semakin besar. Dari Tabel 10 dapat diketahui pula estimasi VaR dari tiap model menghasilkan standard error yang sangat kecil. 
Apabila diilustrasikan seorang investor melakukan investasi sebesar Rp 50 juta, menggunakan metode copula diperoleh ringkasan nilai kerugian maksimum yang mungkin diperoleh satu hari kedepan disajikan dalam Tabel 11 berikut:

Tabel 11. Estimasi nilai kerugian maksimum.

\begin{tabular}{ccl}
\hline Keluarga Copula & Tingkat Kepercayaan & Nilai Kerugian \\
\hline \multirow{3}{*}{ D-Vine Frank } & $90 \%$ & $\operatorname{Rp~} 928.009$ \\
\cline { 2 - 3 } & $95 \%$ & $\operatorname{Rp~} 1.281 .152$ \\
\cline { 2 - 3 } & $99 \%$ & $\operatorname{Rp~} 2.244 .595$ \\
\hline
\end{tabular}

Nilai dalam Tabel 11 menunjukkan nilai kerugian yang mungkin akan diperoleh satu hari ke depan pada masing-masing tingkat kepercayaan. Hasil tersebut dapat diinterpretasikan sebagai estimasi kerugian maksimum yang mungkin diperoleh satu hari ke depan oleh portofolio yang terdiri dari saham BBNI, BBRI, dan BMRI dengan tingkat kepercayaan 90\%, 95\%, dan 99\%.

\section{Kesimpulan}

Penerapan metode GARCH-Vine Copula untuk estimasi Value at Risk (VaR) pada saham perbankan LQ45, yaitu BBNI, BBRI, dan BMRI periode 26 Agustus 2013 sampai dengan 20 November 2017 menghasilkan estimasi VaR dengan copula terbaik adalah Frank D-Vine Copula sebesar 1,86\%; 2,56\%, dan 4,49\% dari dana investasi pada tingkat kepercayaan 90\%, 95\%, dan 99\%. Apabila diilustrasikan seorang investor melakukan investasi sebesar $\mathrm{Rp} 50.000 .000,00$ nilai kerugian maksimum yang mungkin diperoleh satu hari kedepan pada tingkat kepercayaan 90\%, 95\%, dan 99\% tidak akan melebihi sebesar Rp 928.009, Rp 1.281.152 dan Rp 2.244.595.

Penelitian ini terbatas pada penggunaan keluarga Copula Archimedean, yaitu Copula Clayton, Gumbel, dan Frank, sehingga untuk penelitian selanjutnya dapat dikembangkan perhitungan VaR menggunakan keluarga Copula Archimedean yang lain seperti Joe Copula atau keluarga Copula Elliptical. Selain itu pada penelitian ini diasumsikan ketiga saham memiliki bobot yang sama yaitu $\frac{1}{n}$ , sehingga untuk penelitian selanjutnya dapat digunakan metode pembobotan yang berbeda.

\section{Referensi}

[1] Bollerslev, T. , Engle, R., Nelson, D. 1994. ARCH Models. Econometrics. (31): 307-327.

[2] Dharmawan, K. 2014. Estimasi Nilai Value at Risk Portofolio Menggunakan Metode t-Copula. Jurnal Matematika, Saint, dan Teknologi.

[3] Geidosch, M., Fischer, M. 2016. Application of Vine Copula to Credit Portfolio Risk Modelling. Jurnal of Risk and Financial Management.

[4] Halim, A. 2005. Analisis Investasi (Edisi Kedua). Jakarta, Salemba Empat.

[5] Hanke, J. E., Wichern, D. W. 2005. Business Forecasting ( $\delta^{\text {th }}$ ed.). New Jersey, Pearson Prentice Hall.

[6] Joe, H. 1997. Multivariate Models and Dependence Concept. London, Chapman and Hall.

[7] Joe, H., Xu, J. J. 1996. The Estimation Method of Inference for Multivariate Models. Technical Report 166.

[8] Jorion, P. 2002. Value at Risk : The New Benchmark for Managing Financial Risk (2 ${ }^{\text {nd }}$ ed.). New York, Macmillan.

[9] Liu, J. 2011. Extreme Value Theory and Copula Theory : A Risk Management Application with Energy Futures. University of Victoria, Victoria.

[10] Matteis, R. D. 2001. Fitting Copulas to Data. Thesis. University of Zurich, Zurich.

[11] Nelsen, R. B. 2006. An Introduction to Copulas (2 ${ }^{\text {nd }}$ ed.). New York, Springer.

[12] Renggani, P., Pintari, H. O., Subekti R. 2017. Estimasi Value at Risk (VaR) pada Portofolio dengan Metode Elliptical Copula. Prosiding, Seminar Matematika dan Pendidikan Matematika 2017. FMIPA UNY, 11 November 2017: 89-96.

[13] Rosadi, D. 2014. Analisis Runtun Waktu dan Aplikasinya dengan R. Yogyakarta, Gadjah Mada University Press.

[14] Siegel, S. 1990. Statistik Nonparametrik untuk IImu-ilmu Sosial (Terjemahan Zanzawi Suyuti dan Landung Simatupang). Jakarta, PT Gramedia Pustaka Utama.

[15] Suharto, A. A. P., Dharmawan, K., Sumarjaya, I. 2017. Estimasi Nilai VaR Portofolio Menggunakan Fungsi Copula Archimedean. E-Jurnal Matematika 6. (1): 15-21.

[16] Tsay, R. S. 2005. Analysis of Financial Time Series (2nd ed.). New York, John Wiley \& Sons, Inc.

[17] Wei, W. W. 2006. Time Series Analysis : Univariate and Multivariate Methods (2 ${ }^{\text {nd }}$ ed.). New York, Addison Weasley. 